\title{
Comparative Study of the Nutritional Content of White Button Mushroom [Agaricus bisporus (Lange) Imbach] after Application of Pseudomonas putida
}

\author{
Binit Kumar*, Chanchila Kumari and Manish Kumar \\ Indian Council of Agricultural Research-National Rice Research Institute, \\ Central Rainfed Upland Rice Research Station, Hazaribag, Krishi Vigyan Kendra, \\ Koderma (Jharkhand), India \\ *Corresponding author
}

\section{A B S T R A C T}

\begin{abstract}
The white button mushroom (Agaricus bisporus) is very popular throughout the world and is the most important mushroom of commercial significance in India. It can be successfully cultivated in places where the environmental conditions are favorable but it is cultivated in North India in winter seasons due to the favorable conditions. The optimum temperature for mycelial growth is $20^{\circ} \mathrm{C}-25^{\circ} \mathrm{C}$ and that for fruit body formation $15^{\circ} \mathrm{C}$ $20^{\circ} \mathrm{C}$ and a high percentage of relative humidity $(80-85 \%)$. The experiment was designed to evaluate the effect of bio-inoculants on the growth, yield and biochemical content of white button mushroom. Wheat straw supplemented with wheat bran was used for compost and application of Pseudomonas putida in casing layer was done by sprinkling of water. The casing combinations Garden Loam soil (GLS)+ Farm Yard Manure (FYM)+ Vermicompost (VC)+ Waste tea leaf + Pseudomonas putida $\left(10^{8}\right.$ c.f.u. $\left./ \mathrm{ml}\right)$ was gave significant difference in all the parameters i.e. minimum days required for fruitification (10.3 days), number of fruiting bodies per bag (94.3), fresh weight $(1.02 \mathrm{~kg})$, protein $(0.34 \mathrm{mg})$, carbohydrate $(0.26 \mathrm{mg})$, moisture content $(89.5 \%)$ and biological efficiency (20.24\%) in comparison to non-supplemented casing layer with same combination. This research was focused upon the evaluating the nutritional content of white button mushroom after addition of bio-inoculants as a bio-fertilizer in casing layer.
\end{abstract}

\section{Introduction}

Mushroom production is a growing business in India as the demand is increasing from last few years. It is a matter of practice and technical knowledge rather than labor intensive farming with a high value of return in short time. Mushroom production has some key raw materials to get good yields.
Mushrooms and other fleshy fungi are the premier recyclers of nutrients on the planet (Stamets, 2000). Yet to date, the inherent biological power embodied within the mycelium network of mushrooms largely remains a vast, untapped resource. Water defines the biosphere, and low water availability in arid regions of the globe limits biodiversity as well as biomass (Austin et al., 
2004; Huxman et al., 2004). Saprotrophic basidiomycete macrofungi have a worldwide distribution and play critical roles in water sequestration, animal and human nutrition, soil health and ecosystem function, particularly in water-constrained environments (McGonigle, 1995; Austin et al., 2004). Spawn, Compost and Casing Soil are three raw materials are used in it. To promote sporophore production in button mushroom, a relatively biological inert material is added as surface layer to the fully colonized compost. This casing layer is usually $5-8 \mathrm{~cm}$ thick and usually applied after approximately 15-20 days of spawning. Casing layer prevents quick drying of spanned compost. After casing is complete, a period called "case-running" follows wherein casing itself is colonized by mycelium. Optimal environmental conditions for two mycelial-run phases are essentially the same. The casing materials gave a broad range for doing modification and increase of yield as well as biochemical content by using biofertilizer during casing. Bio-inoculants play a significant role in basidiocarp initiation in $A$. bisporus. The bio-inoculants are used as a biofertilizer, which enhance the growth and yield of white button mushroom. Ahlawat and Rai first investigated use of bio-inoculants in the mushroom growing media in the year of 1997. Microbial biomass constitutes 2\% of compost weight and act as a concentrated source of nitrogen and minerals for mushroom mycelium (Wood and Smith, 1987). Thermophilic microbes such as fungi and bacteria play an important role in preparing the selective media for the button mushroom. Further investigation reveal that, use of bacterial inoculants gives many benefit such as nitrogen supply for spawn compost, control of weed fungi, enhanced yield and biochemical constituents of A. bisporus. Mushroom cultivation is gaining commercial importance in recent years due to the fact that global demand for protein will be double in future and it will be possible to satisfy this future requirement by only conventional agricultural methods.

\section{Materials and Methods}

The investigation was set up at ICAR-NRRICRURRS-KVK, Koderma, Jainagar to evaluate effect of bio-fertilizer on nutritional content as well as yield of white button mushroom. Regarding the work objective, initial step was preparation of compost for that the substrate used for button mushroom is a prepared by LCM method according to the available research materials (Mantel et al., 1972). It is completely outdoor practice completed in 28-30 days. The constituents include in the formulations, ensure the initial Nitrogen levels at 1.5-1.75 and final level at $1.25 \%$. The Carbon: Nitrogen lay in between 25 and 30 at beginning and 16-18 in the end (Shashank Maheshwari, 2013). The straw is thoroughly wet for $24 \mathrm{hr}$. and mixed with the wheat bran and fertilizer separately. The substrate prepared was formed into a large heap of 5 feet width and 7 feet height to encourage intense microbial activities causing the generation of heat reaching up to $70^{\circ} \mathrm{C}-$ $80^{\circ} \mathrm{C}$. This heap is broken on the 4th day and remade after adding the bran and fertilizer mixture slurry made with molasses, and insecticides in 50 liters of water. This breaking and remaking process is called turning. Turing has to be done every 3-4 days after adding water to maintain around $75 \%$ moisture and allowing passing the air and getting the aerobic conditions. Gypsum is added at 3rd at turning and the compost is ready for spawning after 7th or 8th turning, otherwise more turnings are necessary until it is completely free form ammonia (Table 1).

Crop room was sterilized by spraying formaldehyde solution ( 2.0 percent) by foot sprayer and air tight for $48 \mathrm{hrs}$. After $48 \mathrm{hr}$ fresh air is allowed to introduce and then these cropping rooms were used for cultivation 
experiments. After composting, compost were filled in the polytheen bags $(50 \times 30 \times 10 \mathrm{~cm})$ @ $10 \mathrm{~kg}$ per bag. The spawning rate was $75 \mathrm{~g}$ per bag mixed throughout in compost (Kapoor, 2004). The commercial spawn was procured from Birsa Agricultural University, Ranchi, Jharkhand. The spawned compost are kept covered with $2 \%$ formalin dipped unprinted newspaper sheets by closing the mouth of the bags. Temperature are then maintained at $24^{\circ} \mathrm{C}$ in the culture room, with relative humidity maintained between 80$85 \%$, Mushroom mycelia start impregnation within 2-3 days after spawning and completed in10-16 days under congenial condition.

The selected basic material for preparation of casing soil such as Farm yard manure, garden loam soil, waste tea leaf and Vermicompost were collected from locality and sterilized by $2 \%$ formalin solution before used. The most commonly used casing material is the peatmoss, and is directly used for casing after adjusting the $\mathrm{pH}$ with lime or chalk and pasteurization. However, but Peat moss is unavailable in India, so one of the following combination of casing mixture was investigated with the application of biofertilizer to enhanced nutritional properties of Agaricus bisporus (Table 2).

The mass multiplication of $P$. putida was done in broth King's B medium and inoculated on casing layer by spray. Composition of King's B comprises of Proteose peptone 20g, Glycerol 10ml, $\mathrm{K}_{2} \mathrm{HPO}_{4} 1.5 \mathrm{~g}, \mathrm{MgSO}_{4} \cdot 7 \mathrm{H}_{2} \mathrm{O}$ $1.5 \mathrm{~g}$, Agar $20 \mathrm{~g}$ and Distilled water $1000 \mathrm{ml}$ (King el al., 1954). Dilution plate techniques were applied for counting of bacterial cells $/ \mathrm{ml}$ (Aneja, 2004). Protein and Carbohydrate content of mushrooms were estimated by the Lowry et al., 1951 and Brink et al., 1960 respectively. The biochemical analysis was done in the laboratory of plant pathology at ICAR-NRRI-CRURRS, (Jharkhand).

\section{Results and Discussion}

The environmental factors play an important role in development of microorganism i.e. Temperature, Humidity, Aeration and availability of micro nutrients (Kumar et al., 2017). Hence all the necessary condition for optimum growth was maintained in growing room during conduction of trails on Agaricus bisporus with bio-fertilizer (Pseudomonas putida). In period of cropping temperature and humidity monitored, it was observed that the maximum room temperature falls $19-27^{\circ} \mathrm{C}$ for spawn run and the minimum temperature was in range of $15-18^{0} \mathrm{C}$ for fruit body formation besides relative humidity was noted up to 80 90 percent (Table 3 ).

Examination of data which was collected during inception to compilation of experiment revealed that respective application of microbial inoculants i.e. Pseudomonas putida in combination of casing mixture GLS+ $\mathrm{FYM}+\mathrm{VC}+$ waste tea leaf in the ratio $2: 1: 1: 1$ gave significant improvement in growth, yield, bio-chemical content and other morphological parameters of white button mushroom.

Possible all the parameters for white button mushroom covered in present study. Between the inoculated and non-inoculated treatment combination of same casing mixture with $P$. putida @ $10^{8}$ c.f.u. $/ \mathrm{ml}$ resulted significant difference in minimum days took for complete mycelium run 10.3 days, maximum number of fruiting bodies harvested 94.3 per bag, average fresh weight of total harvested fruiting bodies $1.02 \mathrm{~kg}$ per bag, protein content $0.34 \mathrm{ml}$ per $10 \mathrm{~g}$, carbohydrate content $0.26 \mathrm{ml}$ per $10 \mathrm{~g}$ and moisture 89.5 percent. Rather non-inoculated gave 15.3 days for mycelium run followed by $0.80 \mathrm{~kg}$ per bag average fresh weight of fruiting bodies, protein content $0.24 \mathrm{ml}$ per $10 \mathrm{~g}$, carbohydrate content $0.22 \mathrm{ml}$ per $10 \mathrm{~g}$ and moisture content 69.4 percent (Fig. 1-5). 
Table.1 Parameters of compost at the time of spawning

\begin{tabular}{|c|c|c|}
\hline S.N. & Parameters of compost & Contents \\
\hline $\mathbf{1}$ & Nitrogen & $1.25 \%$ \\
\hline $\mathbf{2}$ & Phosphorus & $1.12 \%$ \\
\hline $\mathbf{3}$ & $\mathrm{pH}$ & 7.21 \\
\hline $\mathbf{4}$ & Moisture & $75 \%$ \\
\hline $\mathbf{5}$ & Bulk density & $0.57 \mathrm{~g} / \mathrm{ml}$ \\
\hline $\mathbf{6}$ & Colour & Dark Brown \\
\hline $\mathbf{7}$ & C:N & $16: 18$ \\
\hline $\mathbf{8}$ & Temperature & $70-80$ \\
\hline
\end{tabular}

Table.2 Detail of treatment combination

\begin{tabular}{|l|l|}
\hline S.N & \multicolumn{1}{c}{ Combination of Casing mixture } \\
\hline $\mathbf{T}_{\mathbf{1}}$ & $\begin{array}{l}\text { Garden loam soil }(\mathrm{GLS})+\text { Farm Yard Manures }(\mathrm{FYM})+\text { Vermicompost }(\mathrm{VC})+\text { waste tea } \\
\text { leaf }(2: 1: 1: 1)\end{array}$ \\
\hline $\mathbf{T}_{\mathbf{2}}$ & $\begin{array}{l}\text { Garden loam soil }(\mathrm{GLS})+\text { Farm Yard Manures }(\mathrm{FYM})+\text { Vermicompost }(\mathrm{VC})+\text { waste tea } \\
\text { leaf }(2: 1: 1: 1)+P . \text { putida }\left(10^{8} \text { c.f.u./ml. }\right)\end{array}$
\end{tabular}

Table.3 Effect of casing mixture on yield and bio-chemical content of A. bisporus

\begin{tabular}{|c|c|c|c|c|c|c|c|c|}
\hline S.N & Treatment combination & AD & FW & NFB & PC & CC & $\begin{array}{c}\text { BE } \\
\%\end{array}$ & MC\% \\
\hline $\mathbf{T}_{\mathbf{1}}$ & GLS+ FYM+ VC+ waste tea leaf $(2: 1: 1: 1)$ & 15.3 & 0.80 & 79.2 & 0.24 & 0.22 & 15.2 & 69.4 \\
\hline $\mathbf{T}_{\mathbf{2}}$ & $\begin{array}{c}\text { GLS+FYM+VC+waste tea leaf }(2: 1: 1: 1)+ \\
\quad\end{array}$ & 10.3 & 1.02 & 94.3 & 0.34 & 0.26 & 20.2 & 89.5 \\
\hline
\end{tabular}

AD: Avg Days, FW: Fresh Weight, NFB: Number of Fruiting body per bag, PC: Protein content,

$\mathrm{CC}$ : Carbohydrate content, BE: Biological efficiency, MC: Moisture content in compost

Fig.1 Preparation of Compost. Fig.2 Preparation of Compost pile. Fig.3 Placement of spawned bags in mushroom crop room. Fig.4 Mycelium run on compost. Fig.5 Fruiting bodies of Agaricus bisporus
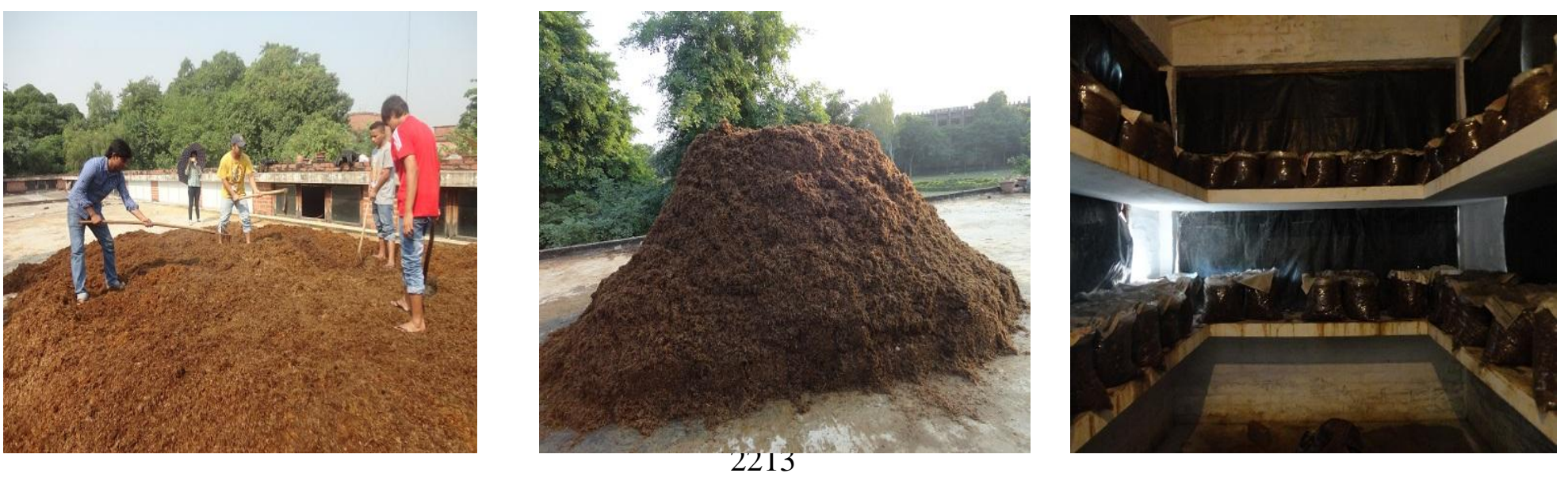


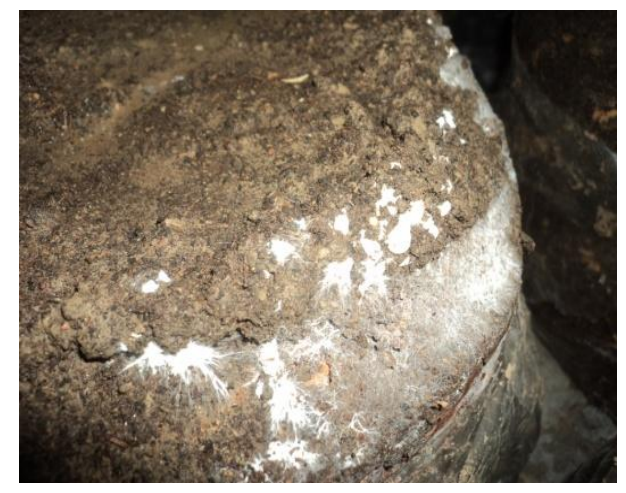

The comparison of data on various parameters also revealed that the performance of $P$. putida inoculants was more noticeable as compare to non-inoculation ones. However, the result of present study emphasizes more stress on effect of bio-inoculants with combination of GLS+ FYM+ VC+ waste tea leaf either alone or in combination for $A$. bisporus. The physio-chemical, porosity, bulk density, $\mathrm{C}: \mathrm{N}$ ratio, $\mathrm{pH}$ value and availability of micro and macro nutrient properties of casing mixture favored the activity of microorganism in casing layer and increase the yield as well as nutritional content of white button mushroom, these probable reasons has been supported by many mushroom workers on different cultivable, edible mushroom (Haddad, 1978; Ahmed et al., 2009 and Kumar et al., 2017). Pseudomonas putida has been found active in promoting the fruiting in button mushroom. The activity of $P$. putida in casing soil is the result of environment created by growing mycelium.

It is suggested that $P$. putida releases iron which stimulates fructification. Thus, from the present investigation it can be concluded that the treatment GLS+ FYM+ VC+ waste tea $+P$. putida $\left(10^{8}\right.$ c.f.u. $\left./ \mathrm{ml}\right)$ of casing was found to be very effective because it showed, reduction in days required for pinhead initiation, days required for button formation and other parameters over non-inoculated casing in A. bisporus.

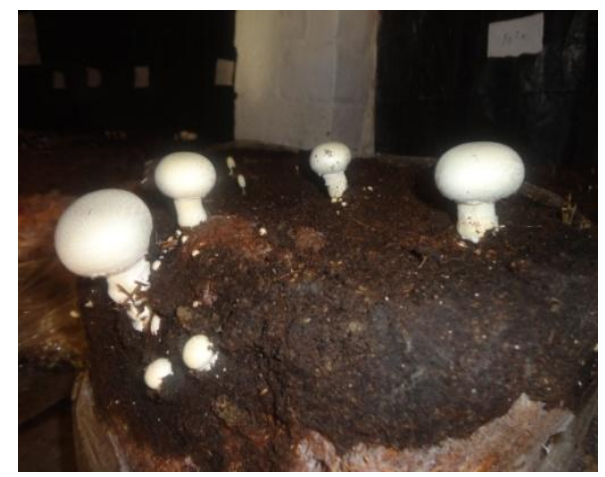

\section{References}

Ahlawat, O.P. and Rai, R.D. 1997. Effect of 'Azotobacter' and 'Phosphotika' biofertilizers on the spawn run, pinning and yield of white button mushroom (Agaricus bisporus). Mush. Res. 6:6974.

Ahmed, S.A, Kadam, J. A, Mane, V.P, S.S, Patil and Baig, M. M.V.2009. Biological Efficiency and Nutritional Contents of Pleurotus florida (Mont.) Singer cultivated on different Agrowastes. Nature and Science, 7 (1): 4448.

Aneja, K. R. 2004. Experiments in Microbiology, Plant Pathology and Biotechnology. $4^{\text {th }}$ edition, New age International (P) limited, Publisher. 506-514.

Austin, A.T., Yahdjian, L., Stark, J.M, Belnap, J., Porporato, A., Norton, U., Ravetta, D.A., and Schaeffer, S.M. 2004. Water pulses and biogeochemical cycles in arid and semiarid ecosystems. Oecologia. 141: 221-235.

Haddad, N.A. and W.A. Hayes, 1978. Nutritional factors and the composition of the Agaricus bisporus mycelium. Mush. Sci, 10:715-722.

Huxman, T. E., Smith, M.D., Fay, P.A., Knapp, A.K., Shaw, M.R., Loik, M.E., Smith, S.D., Tissue, D.T., Zak, J.C., Weltzin, J.F., Pockman, W.T., Sala, O.E., Haddad, B.M., Harte J., Koch, 
G.W., Schwinning, S., Small, E.E., and Williams, D.G. 2004. Convergence across biomes to common rain-use efficiency. Nature. 429: 651-654.

Kapoor, J. N. (2004). Mushroom cultivation. Department of Mycology and Plant Pathology, IARI, New Delhi, 14-15.

King, E. O., Ward, M. K. and Raney, D. E. 1954. J. Lab and Clin. Med. 44:301307.

Kumar, B., Kumari, C., Kumar, M. and Singh, V K. 2017. Conversion of agricultural by Products: Mushroom cultivation, IJCSR. 3(10): 2454-5422.

Kumar, B., Kumari, C., Kumar, M. and Singh, V K. 2017. Effect of waste tea leaf and slake lime in casing mixture on yield of white button mushroom Agaricus bisporus (Lange) Imbach]. IJCSR. 3(11): 1452-1457.
Maheshwari S. 2013. A Guide for White Button Mushroom (Agaricus bisporus) Production. 2: 668.

Mantel, E. F. K, Agarwal, R. K. and Seth, P. T. 1972. A guide to mushroom cultivation. Ministry of Agriculture, Farm Information Unit, Directorate of Extension, New Delhi, 2.

McGonigle, T.P. 1995. The significance of grazing on fungi in nutrient cycling. Canadian $J$ of Botany- Revue Canadienne Botanique. 73: 1370-1376.

Stamets, P. 2000. Growing gourmet and medicinal mushrooms. 3 ed. Ten Speed Press, Berkeley. 574.

Wood, D.A., and Smith, J.F. 1987. The cultivation of mushroom (Part III), Reproduced form essay in Agricultural and food Microbiology (Eds.) Norris, J.R. and G.L. Pettipher, John willey and sons Ltd.

\section{How to cite this article:}

Binit Kumar, Chanchila Kumari and Manish Kumar. 2018. Comparative Study of the Nutritional Content of White Button Mushroom [Agaricus bisporus (Lange) Imbach] after Application of Pseudomonas putida. Int.J.Curr.Microbiol.App.Sci. 7(02): 2210-2215. doi: https://doi.org/10.20546/ijcmas.2018.702.266 